\title{
Exploring Causes of Bribery: A Case Study in a Public Organization in Malaysia
}

\author{
Malini Sathappan \\ Department of Professional Development and Continuing Education \\ Faculty of Education Studies, Universiti Putra Malaysia \\ Zoharah Omar (Corresponding author) \\ Department of Professional Development and Continuing Education \\ Faculty of Education Studies, Universiti Putra Malaysia, Serdang, Malaysia \\ Email: omarzoharah@gmail.com
}

Ismi Arif

Department of Professional Development and Continuing Education

Faculty of Education Studies, Universiti Putra Malaysia, Serdang, Malaysia

\author{
Ramesh Sathappan \\ Department of Languages, Institute Pendidikan Guru, Temenggung Ibrahim \\ Johor Bahru, Malaysia
}

Received: July 15, 2016 Accepted: August 13, 2016 Published: August 19, 2016 doi:10.5296/ijhrs.v6i3.9812 URL: http://dx.doi.org/10.5296/ijhrs.v6i3.9812

\begin{abstract}
Purpose: The purpose of the research paper is to explore and understand the causes of bribery among law enforcement officers in Malaysia.

Methodology: Qualitative method was used in this research paper. Data collected using semi structured interview, documents and field observation. The research used non-random sampling among seven various rank officers. Furthermore it is an exploratory study as it
\end{abstract}


explores causes of bribery among law enforcement officers in Selangor state.

Findings: The findings derived four themes based on the cause of bribery namely (1) family, (2) public, (3) individual and (4) organization. Law enforcement officers believed bribery is a cause of officers being suspended and terminated from their job. Additionally a model has been developed on causes of bribery.

Practical implications: Findings showed that practices of bribery among various level of officers who have to work together to address the issue of bribery in Malaysian law enforcement agency through formulated policies and strategies.

Originality/value: This study may assist Malaysian enforcement agencies in identifying causes and overcoming bribery. It also provided a clear idea about how the cause of bribery can influence the behavior of an officer which can harm an organization.

Keywords: Bribery, Misbehavior, Law enforcement officer, Causes

\section{Introduction}

Previous research have identified misbehavior such as workplace bully, sexual harassment, consumption of drugs, consumption of alcohol at work, bribery, lateness, absenteeism and stealing. Even though there are many studies related to types and causes of misbehavior but this study will be mainly focusing on bribery and its causes.

Bribery is significant to be studied due to social and economical costs of a country. Moreover it will discourage small business, entrepreneurs, consumers and foreign investments. Besides that it will damage reputation and respect towards law, public and financial institutions. It will create conducive environment for crime in the private and can organize crime (German, 2002). Bribery and corruptions are regarded as major impediments to development in developing countries (Gordon et al., 2001) Robert and Barker (1974) has classified bribery as a type of corruption. Thus examining the impact of bribery is encouraged because International transparency index 2015 showed Malaysia ranked as $50^{\text {th }}$ place among 168 countries. This indicates it is a major concern for researchers to investigate on causes of bribery. Furthermore antecedents of bribery are different in multi-cultural settings (Ramamoorthy, 2015).

However looking at Malaysian context, scholars have conducted research on testing relationship between job satisfaction and personality environment, testing competencies on RMP, change management, quality of work life, leadership, factors influencing attitudes against organizational change and report on royal commission (Rojiah, 2006; Haron, 2006; Rizal, 2011; Hashim, 2010; Awang, 2011; Kadir \& Jusoff, 2009). Exploring causes of bribery may lead to little understanding of bribery from Malaysian law enforcement perspective.

\subsection{Significance of the Study}

Bribery is the topic which is rarely discussed compared to other types of misbehavior among law enforcement agencies in Malaysia. Study of the existence of bribery among law 
enforcement agencies is going to help HR managers to prevent decline in organizational outcomes, commitment and performance among employees at all levels. This may lead to organizational decrease in productivity, loss in financial costs, low commitment, poor organizational culture, job dissatisfaction and intention of turnover (Rogojan, 2009). Investigation on bribery will be helpful to identify causes of bribery and easier for HR managers and researchers to solve the issues and create a healthy climate at workplace. This study will extend the existing body of knowledge on the subject of bribery. From a theoretical perspective, the study would provide a comprehensive and valuable understanding of the model constructed and illustrated in the discussion section. Finally, this study can create an awareness of ethics involved in human resource development. Moreover, it is also vital for law enforcement officers' effectiveness and accountability in monitoring employees' ethical behavior at workplace.

\subsection{Contribution of the Study}

The human resource development does not have an integrative review of bribery in the workplace. While there was a substantial amount of research found on bribery in Asia. But an integrative review was not found in enforcement agency in Malaysia. Firstly, bribery is a major concern in workplace settings. This research paper has provided a comprehensive view of causes of bribery and developed a model to explain when studying the topic. Second bribery is a topic that impacts the human resource of an organization. From this perspective a variety of training and development programs could be examined to curb bribery and the outcomes of bribery that could possibly increase unethical behavior of enforcement officers. Providing this comprehensive perspective gives key areas to address in training and development.

\section{Research Objective}

The purpose of the study aims to identify causes of bribery and understand the nature of the process among various positions of employees in the enforcement agency. The need for such a research is essential due to employees are suspended, terminated and work withdrawals are occurring at workplace.

\section{Literature Review}

This research paper is based on previous findings, theory and model of causes of bribery.

\subsection{Bribery}

Bribery has been defined as an immoral and unethical practice and economic harm its causes falls most heavily on those least able to absorb it (Cleveland, Favo, Freeka and Owens, 2009). Furthermore Weber and Getz (2004) defined bribery as a "transaction involves at least 2 people, The payer (supplier) and the receiver (or demander). Either actor can be a member of the public or the private sector. Most business transaction payers are private actors and the receiver is a public actor. If the payer initiates the transaction, it is a bribe but if the receiver demands a payment, it is extortion". Previous research findings from Khalil, Lawaree and Yun (2010) highlighted differences between bribery and extortion. Bribery involves 
cooperation between corrupt parties and it leads to extortion. Bernadi, Witek and Melton (2009) reported participants reported bribing a police officer to escape from the eyes of law is considered as minor offence compared to selling defective product, overstating a repair bill and bribing board members. Therefore it is evident that police officers are not the only people involved in deviant activity but the public is also a cause of it. Bribery exists due to corrupt network provided by a country (Lauchs, Keast and Yousefpour, 2011).

\subsection{Social cognitive theory (Albert Bandura, 1986)}

Researchers have used social cognitive theory as a foundation in explaining misbehavior among employees at various organizations. Social cognitive theory suggests that cognitive part of a human is a tool for individuals to accomplish the tasks and goals that give meaning and direction to their lives (Harre \& Gillet, 1994). According to this theory cognitive and other personal factor, together with environmental influences all operate interactively as determinants of each other (Bandura, 1986, p.23). Personal factor in this study represent individual differences such as locus of control, empathy, trait, cynicism and moral identity. Whereas environmental factor refers to organizational ethical climate. Example organizational procedures, policies and practices with moral consequences (Martin \& Cullen, 2006 p. 177). Therefore, social cognitive theory shows that the cognitive part of a human is a tool for individuals to accomplish the tasks and goals that give meaning and direction to their lives (Harre \& Gillet, 1994). Based on this theory it can be argued that enforcement officers involve in bribery due to environmental threats and temptations.

\subsection{Anomie theory (Robert Merton, 1957)}

Anomie theory postulates self-interests and desires of citizens in a society can only be controlled by forces that originate from the individual. These forces are ideas, values, norms, ideologies and beliefs of the culture. These are institutionalized in the social structure and internalized by individual members of the group. Durkheim argued if an individual lacks any source of social restraint, that person would tend to attempt to satisfy personal needs, disregarding the possible effect this might have on others in society (Solomons, 2010). To meet the ends he or she does not think or care for others.

\subsection{Social learning theory (Aker, 1963)}

Social learning theory is an extension of Sutherland's differential association theory to explain acts that violates social norms. Social learning theory contains four variables such as differential association, definitions, reinforcement and modeling. The above four variables will balance an individual behavior whether he or she will engage in negative behavior. This theory explains an individual will be influenced by the person whom one associates frequently or interactions with peers. The police subculture provides an opportunity to learn deviant activity because attitudes, values and beliefs are transmitted from one generation to another in a learning process (Kappeler, Sluder \& Alpert, 1998). Example police corruption is a transmission of cultural values via the influence of a reference group (Sherman, 1978). Previous researchers (Kane \& White, 2009; Mawritz et al, 2012; Sherman, 1978 and Chapell $\&$ Piquero, 2004) applied this theory to explain misbehavior among police officers. 


\subsection{Social Control Theory (Hirschi, 1969)}

This theory argues that bonds to conventional social institutions such as family, religion and schools may help keep an individual from engaging into negative behavior. Hirsch developed four elements that outline the ties that one has to society. First attachment second is commitment followed by involvement and acceptance. Rothwell (2009) mentioned the above four elements are linked to delinquency of organizational misbehavior. Scholars Baek, Kang and Park (2004); Peguero \& Shekarkhar (2011) also applied this theory in their studies based on university and school students. Whereas Solomons (2010) applied this theory to explain about decision making process of police officers.

\subsection{Vardi and Wiener's Model (1992, 1996).}

Vardi and Wiener (1996) explained the cause of misbehavior is due to two major independent forces such as the instrumental force reflecting beliefs about personal interests and normative force reflecting internalized organizational expectations. Antecedents of this model are individual level, task or position level, group and organizational level. Vardi et al., (1996) have acknowledged misbehavior is directed either to work or organizational property. They classified as type $\mathrm{S}$ (benefit oneself), $\mathrm{O}$ (benefit organization) and $\mathrm{D}$ (instrumental or normative or both).

In answering questions as why law enforcement officers engage in bribery, researchers (Seron, 2004; Maher, 2008; Kane \& White, 2009) have identified minimum education as a cause of misbehavior. While other researchers (Kane, 2002; Weitzer \& Tuch, 2004; Lersch, bazley, Mieczkowski \& Childs, 2008; Ivkovic, 2009; Kane \& White, 2009) mentioned race as an antecedent of misbehavior followed by Schafer (2010) and Gordon (2010) found ineffective leadership is also a cause of misbehavior. Thus shows minimum education, race and ineffective leadership are determinants of misbehavior. Misbehavior in this study refers to bribery which can harm an organization. Scholars such as Quah (2011; 2014) and Ramamoorthy (2015) have argued that low income causes employees to feel dissatisfied and may lead to dysfunctional behavior (bribe). However Gilbert et al., (2016) mentioned bribery among law enforcement officers occurs due to failure of complying with law and not lack of ability.

Notably in last few years the most prevalent cause was peer group factor (Barker, 1977; Reiner, 1992; Benoit \& Dubra, 2004; McClusky, Terrill and Paoline, 2005; Chappell and Piquero, 2004 and Ingram, Paoline \& Terrill, 2013). Behavior of the group is determined by the desire of the majority peer group. These work groups serves as a viable context that patterns culture in police organizations. Furthermore they learn to breach rules from their peer group.

Moreover police sub culture also played a signifying role in influencing law enforcement officers into miscoduct. Police culture creates the impression that officers consider themselves an entity separate from the general population and their survival depends solely on each other. Paolin, 2004 described code of silence when police officers deal with the public, they have strong occupational norm of being loyal to their peer group. In other words 
it is called as us- versus-them. Code of silence is a type of culture being practiced by the police officers. Furthermore it is an illegal behavior which can harm the organization or system failure. Past researchers (Huberts, Lamboo \& Punch, 2003; Westmarland, 2005; Kaarianinen et al., 2008; Anderson, 2011; Cebulak, 2012 and Andresscu., 2012) proved that failure to ethics and integrity may lead to police officer misconduct.

Although past studies (e.g. Anderson, 2011; Loyens, 2009; Kane \& White, 2009; Barker \& Carter, 1977; Maher, 2008; Felson \& Clarke, 1998; Ivkovic, 2009; 2005; Weitzer \& Tuch, 2004; Schafer, 2010; Gordon, 2010; Benoit \& Dubra, 2004; Chappell \& Piquero, 2004; Solomons, 2010; Quah, 2014; 2015, Goldschmidth \& Anonymous, 2008) certainly helped in understanding how code of silence, culture, education, opportunity, race, traits \& habits, power, norms, environment treats and temptations and pressure from management may lead to misbehavior. Therefore exploring causes of bribery among enforcement agency from Malaysian context is much appreciated.

\section{Methodology}

Qualitative method was selected to carry out the research paper. It is a semi-structured interview with law enforcement officers. Researcher would like to explore causes of bribery base on their real life experience at work. The primary data was collected through one to one interview secondary data was collected through documents. Lastly non-participation observation such as researcher was an observer in setting. Sampling technique was snowball sampling. It is a non-probability sampling which researcher begins to identify an individual perceived to be an appropriate respondent.

This study adopts phenomenological case study because it is set to explore experiences of individuals involved in the phenomenon and the data, which serves as a point of interest to the researcher. The purpose is to gain an accurate understanding of another's experiences to capture in-depth reflections by participants regarding their experience of an identified phenomenon (Creswell, 2007). This research paper will be exploring the reported cases of causes of bribery at workplace.

Each interview lasted approximately between 30 to 40 minutes. The questions were based on demographic and open-ended questions discuss on causes of misbehavior. During interview probing questions and throw-away questions were asked. Probing questions were asked to get additional information from respondents. It is common to use throw-away question to build good rapport with respondents. The important part is researchers cultivate respondents to express their feelings freely without having fear in their mind on the research topic. Next researchers transcribed each of the interview session verbatim. After reading the transcription if there were any issue emerge or unclear the researcher will probe in the next interview session. Follow-up discussions were conducted over telephone, through short meetings or electronic mails. Secondly field notes were made as another method of data collection. Finally review of documents such as monthly bulletins, photographs, statistical report on suspended officers, report from ARKIB and annual report 2007 were used to validate the data. 


\section{Data Analysis and Findings}

The study used constant comparative method. It gains inductive category coding with concurrent comparison of all meanings gained in the process of coding to determine similarities and differences (Glaser \& Strauss, 1967). As indicated in table 1 the respondents include 7 male officers. All of them had minimum six years of in service experience and belonged to different departments.

\subsection{Findings}

Table 1. Participant profile

\begin{tabular}{|c|c|c|c|c|}
\hline Respondent & Gender & Position & $\begin{array}{l}\text { Experience } \\
\text { (years) }\end{array}$ & Department \\
\hline 1 & Male & $\begin{array}{l}\text { Middle level } \\
\text { rank }\end{array}$ & 36 & Crime \\
\hline 2 & Male & $\begin{array}{l}\text { Middle level } \\
\text { rank }\end{array}$ & 14 & $\begin{array}{l}\text { Federal reserve } \\
\text { unit }\end{array}$ \\
\hline 3 & Male & $\begin{array}{l}\text { Middle level } \\
\text { rank }\end{array}$ & 14 & Crime \\
\hline 4 & Male & $\begin{array}{l}\text { Middle level } \\
\text { rank }\end{array}$ & 11 & Investigation \\
\hline 5 & Male & $\begin{array}{l}\text { Middle level } \\
\text { rank }\end{array}$ & 8 & Crime \\
\hline 6 & Male & $\begin{array}{l}\text { Middle level } \\
\text { rank }\end{array}$ & 6 & Crime \\
\hline 7 & Male & Low level rank & 6 & General \\
\hline
\end{tabular}

The present section presents the results of this descriptive exploratory study, arranged in context to the research objective.

5.1.1 What are the causes of bribery?

A number of themes were developed based on data collection on causes of bribery, as follows family, individual public and organization as a cause of bribery. Therefore there were four themes derived from the interviews i) family, ii) public, iii) individual and iv) organization. Sub themes of public are categorized as special interest group and friends and acquaintance. Followed by sub theme of individual is religious faith. 


\subsubsection{Family influence}

Family refers to spouse or children. Respondents identified family as children who are ill being in critical situation, lack of finance, love of their family, pressure from the wife, family needs or situation.

Respondent 4 affirmed "family pressure is one of the factors....for example when one of our children is suddenly ill and we do not have any saving and need a lot of money.....a critical situation. From the perspective of the law that is not permissible.....bribe".

Another experience shared by respondent 3 "for instance raid cases, people (officers) take what they are not supposed to take.....family factor perhaps no money, the family are ill. He (officer) sees an opportunity...thus, he grabs without further thinking. This happens everywhere not only in the police force all organizations, including private sector".

Similarly respondent 5 mentioned "it is undeniable as the relationship with the wife is closest. Due to pressure from the wife the officer is easily influenced with deviant behavior (bribe)".

Thus respondent 4, 3 and 5 conveyed family problem persists in some cases. Example accepting bribe is an offence according to rules and regulations of Public Officers (Conduct and Discipline) Amendments regulations 2002. Therefore deviant behavior among law enforcement officers depends on financial needs of a family. If their spouse or children are demanding people then he or she might involve in accepting the offer (bribe).

\subsubsection{Public influence}

Public refers to a group of individual people (Heath, 2005). Respondents of this study referred public as people that know each other through limited number of prior interactions; trust between them is semi-strong or weak. Public influence has been identified as entertainment offers, involvement with wrong guys and comparison with other friends lifestyle. Public influence has been categorized into special interest group and friends and acquaintance.

\subsubsection{Special interest group (SIG)}

Special interest group means a group of people tries to influence other people in political decision making which involves them. This study refers SIG as environment offers and involvement with wrong guys.

Respondent 4 narrated "when there are offers, (bribe).....you know police work, many people want to be friend with the policemen. Entertainment is an offer. Offers are due to the public....example how to settle a case or sir please help......Even though people negotiate, the officer should not take the offer (bribe)".

Thus 4 reported availability of entertainment causes officers to forget their responsibility causes officers to forget their responsibility towards their work. Entertainment here refers to public offering bribe to police officers. So accepting bribe from the public is against the rules of Public Officers (Conduct and Discipline) Amendments regulations 2002. 


\section{1.3.2 Friends and Acquaintance}

Friends and acquaintance refers to people who work in a different occupation or neighbors.

Respondent 2 reported another incident whereby officers are easily influenced while mingling with outsiders (public). "We policemen mix with other people we are carried away. We must make own judgment. We sit down and talk to whom we are different from other people that is why we go for training. The moment you go outside you meet people and you want to behave like them!" 2 was frustrated because some of the officers forget their limitation when they socialize with the public. Officers are sent for training to create awareness that police profession is unique and need to follow guidelines of the police act.

Next respondent 1 further, explained that "compared with other friends lifestyle even though (police officers) have same rank, their friends (neighbors or other profession) has a luxurious life. Thus (police) indulges in bribery. Example traffic police officer is forced by the public". 1 mentioned comparison of lifestyle can influence a person to engage in deviant workplace behavior.

\subsubsection{Individual influence}

Individuals in this study refers to belief, emotion, frustration and stress of a person. Parallel with personality (Barrick \& Mount, 1991), attitudes (Farrell, 1983; Mangione \& Quinn, 1975), frustration (Fox \& Spector, 1999), effect and emotion (Beugre, 1998) and stress (Spector, 1978). Sub themes of individual has been categorized into religious faith.

\section{1.4.1 Religious faith}

Religious means people feel their good and bad deeds are being observed and recorded by god (Geyer \& Baumeister, 2005 p430). Respondents understand is as having lack of faith in god.

Respondent 6 and 4 conveyed "lack of faith may lead them to indulge in bribery. With good religious upbringing and parents who are ok, whichever branch a person is transferred to I think he or she will be ok... (behavior). It is evident that having strong religious faith and belief can influence a person's ethical behavior. Therefore educating ethics through religion is considered as an important element in shaping one's behavior.

\subsubsection{Organizational influence}

Organization is a social unit of people that is structured and managed to meet a need of a collective goals. This research paper has referred organization as law enforcement agency. Law enforcement officers share how organization can be a cause to bribery. The respondents of the study believed co-worker may influence organization's system.

\subsubsection{Co-worker}

Respondents understand co-workers as someone they know, like and trust. A strong form of trust developed through multiple interactions. They are people who work at the same location or department. 
Respondent 7 explained "examples not having the same principle. There are those who may abuse of power. Go "paw" meaning officers who are indulged in getting money (bribe) from public. Some of the officers do not like to involve in this type of behavior. This is called as "crony". They cannot fit into the group. Whereas there are some groups do not like to "paw"money. This reason is called being clannish behavior. This behavior shows groups of people who do not have the same principles while working. Example some of the group may motivate other officers to join in bribery (paw) while patrolling. Unfortunately some of them hesitate to join the group. This may lead into two different groups within the department. Those cannot fit the principles of the group will be discriminated.

\subsection{Discussion}

Family factor was regarded as a cause of bribery. Family was seen as an important unit in the social system. Due to love, affection, concern and need towards family (social system) makes a person engaged in negative behavior. In this study family factor was explained by Anomie theory (Robert Merton, 1957).

Besides that public factor is also another cause of bribery. He or she has a desire to live a comfortable and luxurious lifestyle by comparing friends and neighbors lifestyle. Sometimes they (officers) live beyond their means. When this kind of situation exists (accepting bribe) they tend to forget their role as a law enforcement officer and strive to achieve their goals without making moral judgments. In this situation public is a pushing factor for law enforcement officers to deviate by organization policy and procedures.

However individual factor such as lack of religious faith may cause a person to involve in bribery. Conversly Hirschi's Social control theory explains attachment as the first element of the theory. Attachment is measured as to what degree an individual value the opinions of people and individuals admire such as friends, family, teachers and religious leaders. Individuals reflect on their own views and how sensitive they are to others, less likely to violate the norms. Even though then some of the officers in this study do violate even if they value religion highly. Example accepting bribe from public or supporting clannish behavior among the work groups. Peer group is a cause of bribery because officers learn to breach rules from their co-workers. Social learning theory supports the above findings. Furthermore Vardi's model in this study indicate officers misbehave due to one's benefit which is suitable to type $\mathrm{S}$.

\subsection{The model}

Based on the above discussion this is the model developed on causes of bribery. In this model it is proven that family influence, public influence (special interest group, friends and acquaintance), individual (religious faith) and organization (co-worker) could motivate individuals to engage in bribery. In other words suspended and terminated employees due to bribery had experienced family pressure and public pressure. In order to fulfill their family needs and public needs employees engage in misbehavior at workplace. 


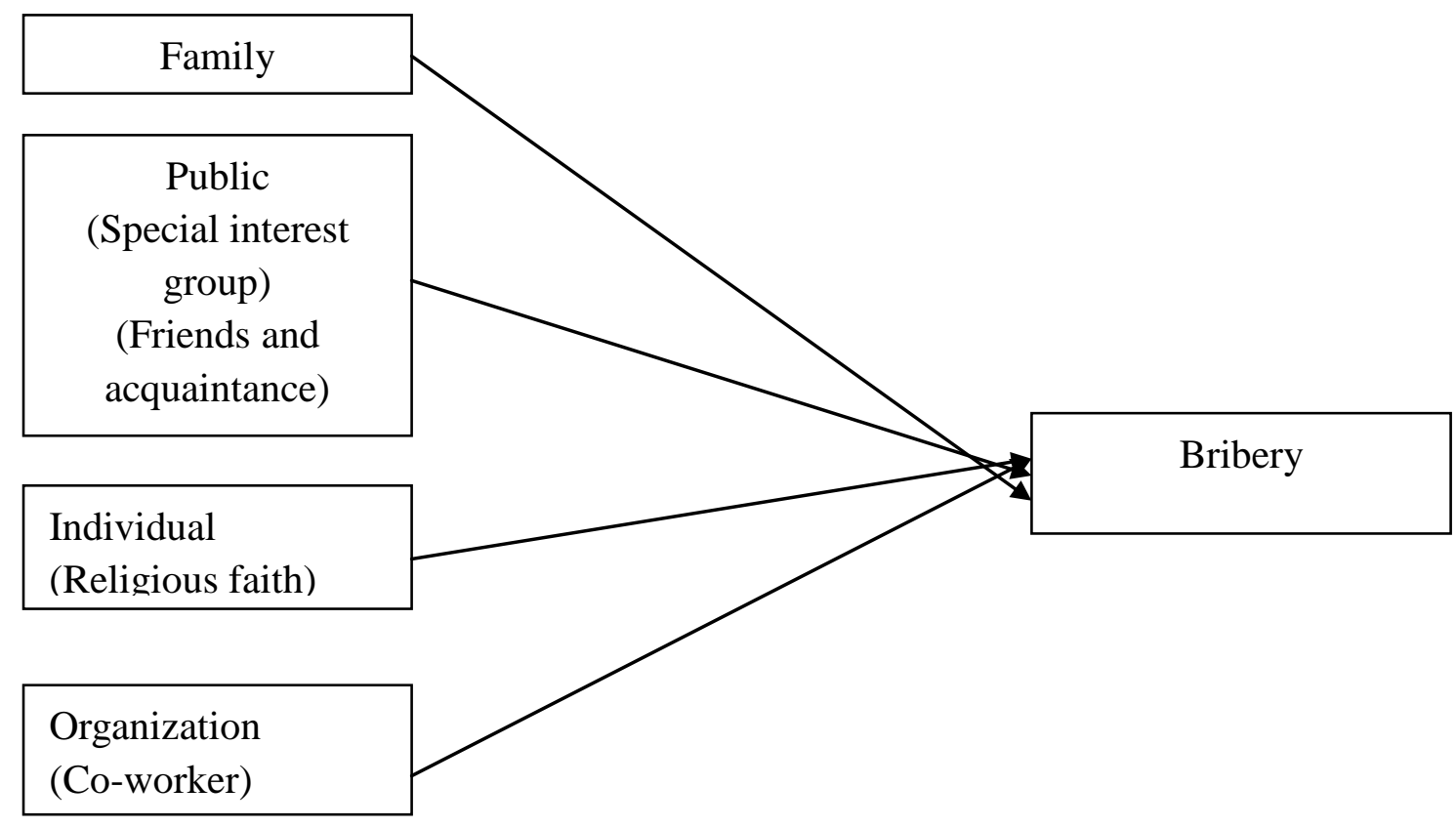

Figure 1: A model on causes of bribery in law enforcement agency

\section{Conclusion and Recommendations}

The social cognitive theory points out the attributes such as locus of control. It plays a significant role in determining a person's moral judgment and reasoning. A person who believes he or she is able to control their destiny has internal control. Those who see their lives and careers as controlled by public and co-worker are considered as external oriented. Therefore, those with an internal locus of control has a higher propensity to establish moral intent and engage in moral acts. Whereas those with an external locus of control has a low propensity in establishing moral intent and engage in moral acts. Therefore it can be concluded that officers who deviate have external locus of control. However this study also reported lack of self-integrity causes an individual fail to obey rules which leads to bribery. Anomie theory proves that persistent family problem due to failure in budgeting financial needs also leads to bribery. Findings of this research paper supported Social learning theory. Conversely findings did not support social control theory.

Research that addresses causes of bribery is warranted. Future research should explore other causes as well. It is recommended to implement ethical training programs and job rotation as a HRD intervention to overcome bribery. 


\section{Macrothink}

\section{Reference}

Anderson, C. W. (2011). Police code of silence: A statistical analysis of the code of silence in law enforcement. (Unpublished doctoral dissertation, University of Western Illinois).

Andresscu, V., Keeling, D. G., Vito, G. F., \& Voinic, M. C. (2012). Romanian \& American police officers perceptions of professional integrity \& ethical behavior. Journal of Revista Romanian De Sociologi, 3(4), 185 - 207.

Awang, H., \& Hariharan, S. (2011). Determinants of domestic violence: Evidence from Malaysia. Journal of Family Violence, 26(6), 459-464.

Baek, J. S., Kang, J. K., \& Park, K. S. (2004). Corporate governance and firm value: Evidence from the Korean financial crisis. Journal of Financial Economics, 71(2), 265-313.

Bandura, A. (1986). Social foundations of thought and action: A social cognitive theory. Thousand Oaks: Prentice-Hall.

Barker, T., \& Carter, D. (1977). Peer group support for occupational deviance. Journal of Criminology, 15(3), 353-366.

Barrick, M. R., \& Mount, M. K. (1991). The big five personality dimensions and job performance: A meta-analysis. Personnel Psychology, 44(1), 1-26.

Benoît, J. P., \& Dubra, J. (2004). Why do good cops defend bad cops? International Economic Review, 45(3), 787-809.

Bernardi, R. A., Witek, M. B., \& Melton, M. R. (2009). A four-country study of the associations between bribery and unethical actions. Journal of Business Ethics, 84(3), 389-403.

Beugre, C. D. (1998). Understanding organizational insider-perpetrated workplace aggression: An integrative model. Research in the Sociology of Organizations, 15, 163-196.

Cebulak, W. (2012). The code of silence as an obstacle in effective police discipline. International Conference on Society and Criminology. Chicago, America

Chappell, A. T., \& Piquero, A. R. (2004). Applying social learning theory to police misconduct. Deviant Behavior, 25(2), 89-108.

Chappell, A. T., \& Piquero, A. R. (2004). Applying social learning theory to police misconduct. Deviant Behavior, 25(2), 89-108.

Cleveland, M., Favo, C. M., Frecka, T. J., \& Owens, C. L. (2009). Trends in the international fight against bribery and corruption. Journal of Business Ethics, 90(2), 199-244.

Creswell, J. W. (2007). Qualitative Inquiry \& Research Design (2nd ed.). Thousand Oaks, CA: Sage.

Farrell, D. (1983). Exit, voice, loyalty, and neglect as responses to job dissatisfaction: A multidimensional scaling study. Academy of Management Journal, 26(4), 596-607. 
Felson, M., \& Clarke, R. V. (1998). Opportunity makes the thief: Practical theory for crime prevention (Vol. 98). Home Office, Policing and Reducing Crime Unit, Research, Development and Statistics Directorate.

Fox, S., \& Spector, P. E. (1999). A model of work frustration-aggression. . Journal of Organizational Behavior, 20(6), 915-931.

German, P. M. (2002). TO BRIBE OR NOT TO BRIBE-a less than ethical dilemma, resolved? Journal of financial crime, 9(3), 249-258.

Geyer, A. L., \& Baumeister, R. F. (2005). Religion, morality and self-control: Values, virtues and vices. In R. F. Paloutzian, \& C. L. Park, Handbook of the psychology of religion and spirituality (pp. 412 - 432). New York, NY: Guilford.

Gilbert, J. A., \& Sharman, J. C. (2016). Turning a blind eye to bribery: explaining failures to comply with the international anti-corruption regime. Political Studies, 64(1), 74-89.

Glaser, B., \& Strauss, A. (1967). The Discovery Grounded Theory: Strategies for Qualitative Inquiry. Chicago: Aldin.

Goldschmidt, J., \& Anonymous. (2008). The necessity of dishonesty: Police deviance, making the case, and the public good. Policing \& Society, 18(2), 113-135.

Gordon, K., \& Miyake, M. (2001). Business approaches to combating bribery: A study of codes of conduct. Journal of Business Ethics, 34(3-4), 161-173.

Gordon, R. D. (2010). Dispersed leadership: Exploring the impact of antecedent forms of power using a communicative framework. Management Communication Quarterly, 24(2), 260-287.

Haron, Z. B. (2006). Kajian Kompetensi Pegawai Kanan Polis Diraja Malaysia Kontinjen Terengganu. Unpublished doctoral dissertation, Universiti Utara Malaysia

Harre, R., \& Gillet, G. (1994). The Discursive Mind. Thousand Oaks, CA: Sage.

Hashim, N. B. (2010). Hubungan antara gaya kepimpinan dengan kepuasan kerja: Kajian kes di Ibu Pejabat Polis daerah seberang Perai Utara, PDRM,. Unpublished doctoral dissertation, Universiti Teknologi Malaysia, Skudai.

Huberts, L., Lamboo, T., \& Punch, M. (2003). Police integrity in the Netherlands and the United States: Awareness and alertness. Police Practice and Research, 4(3), 217-232.

Ingram, J. R., Paoline, E. A., \& Terrill, W. (2013). A multilevel framework for understanding police culture: The role of the workgroup. Criminology, 51(2), 365-397.

Ivković, S. K. (2009). Rotten apples, rotten branches, and rotten orchards. Criminology \& Public Policy, 8(4), 777-785.

Kaarianinen, J., Lintonen, T., Laitinen, A., \& Pollock, J. (2008). The code of silence: Are self-reported surveys available means for studying police misconduct. Journal of Scandinavian Studies in Criminology \& Crime Presentation, 9(2), 86- 96. 
Kadir, N. A., \& Jusoff, K. (2009). The Royal Commission Report for strategic management and improvement of the Royal Malaysian Police. Management Science \& Engineering, 3(3), $28-37$.

Kane, R. J. (2002). The social ecology of police misconduct. Criminology, 40(4), 867-896.

Kane, R. J., \& White, M. D. (2009). Bad cops. Criminology \& Public Policy, 8(4), 737-769.

Kane, R. J., \& White, M. D. (2009). Bad cops. Criminology \& Public Policy, 8(4), 737-769.

Kappeler, V. E., Sluder, R. D., \& Alpert, G. P. (1998). (1998). Forces of deviance: Understanding the dark side of policing. Waveland Press.

Khalil, F., Lawarrée, J., \& Yun, S. (2010). Bribery versus extortion: Allowing the lesser of two evils. The Rand Journal of Economics, 41(1), 179-198.

Lauchs, M., Keast, R., \& Yousefpour, N. (2011). Corrupt police networks: uncovering hidden relationship patterns, functions, and roles. Policing \& Society, 21(1), 110-127.

Lersch, K. M., Bazley, T., Mieczkowski, T., \& Childs, K. (2008). Police use of force and neighbourhood characteristics: An examination of structural disadvantage, crime, and resistance. Policing \& Society, 18(3), 282-300.

Loyens, K. (2009). Occupational culture in policing: Comparison of values in the public and private police. International Journal of Public Administration, 32(6), 461-490.

Maher, T. M. (2008). Police chiefs' views on police sexual misconduct. Police Practice and Research, 9(3), 239-250.

Mangione, T. W., \& Quinn, R. P. (1975). Job satisfaction, counterproductive behavior, and drug use at work. Journal of Applied Psychology, 60(1), 114-116.

Martin, K. D., \& Cullen, J. B. (2006). Continuities and extensions of ethical climate theory: A meta-analytic review. Journal of Business Ethics, 69(2), 175-194.

Mawritz, M. B., Mayer, D. M., Hoobler, J. M., Wayne, S. J., \& Marinova, S. V. (2012). A trickle-down model of abusive supervision. Personnel Psychology, 65(2), 325-357.

McCluskey, J. D., Terrill, W., \& Paoline, E. (2005). Peer group aggressiveness and the use of coercion in police-suspect encounters. Police Practice and Research, 6(1), 19-37.

Paoline, E. A. (2004). Shedding light on police culture: An examination of officers' occupational attitudes. Police Quarterly, 7(2), 205-236.

Peguero, A. A., \& Shekarkhar, Z. (2011). Latino/a student misbehavior and school punishment. Hispanic Journal of Behavioral Sciences. , A. A., \& Shekarkhar, Z. (2011). , 33(1), 54-70.

Quah, J. S. (2011). Curbing corruption in Asian countries: An impossible dream? (Vol. 20). Emerald Group Publishing.

Ramamoorthy, N., Kulkarni, S. P., \& Gupta, A. (2015). To Bribe or Not to Bribe? 


\section{Macrothink}

International Journal of Human Resource Studies

ISSN 2162-3058

2016, Vol. 6, No. 3

Determinants in the Indian Context. European Management Review,12(4), 247-259.

Reiner, R. (1992). The Politics of the Police. Hemel Hempstead: Harvester Wheatsheaf.

Rizal, A. R. (2011). Hubungan antara pengurusan perubahan dan kejayaan sistem maklumat di PDRM. Unpublished doctoral dissertation, Universiti Utara Malaysia.

Roebuck, J. B., \& Barker, T. (1974). A typology of police corruption. Social Problems, 21(3), 423-437.

Rojiah,, A. (2006). Hubungan keseraisan personaliti-persekitaran PDRM dengan kepuasan bekerja. Unpublished doctoral dissertation, Universiti Teknologi Malaysia, Skudai.

Rothwell, V. L. (2009). The Relationship between Attitudes toward Deviance and Deviant Behavior: The Influence of Science, Individualism, Social Bonds and Deviant Peers. Unpublished doctoral dissertation, Virginia Polytechnic Institute and State Universit.

Schafer, J. A. (2010). The ineffective police leader: Acts of commission and omission. Journal of Criminal Justice, 38(4), 737-746.

Seron, C., Pereira, J., \& Kovath, J. (2004). Judging police misconduct: "Street-Level” versus professional policing. Law \& Society Review, 38(4), 665-710.

Sherman, L. W. (1978). Scandal and reform: controlling police corruption. Berkeley, London: University of California Press.

Solomons, W. H. (2010). Understanding a law enforcement officer's decision making process: The influential factors and resultant effects of unethical choice. Unpublished dissertation from Capella University.

Spector, P. E. (1978). Organizational frustration: A model and review of the literature. Personnel Psychology, 31(4), 815-829.

ST Quah, J. (2014). Curbing police corruption in Singapore: lessons for other Asian countries. Asian Education and Development Studies, 3(3), 186-222.

Vardi, Y., \& Wiener, Y. (1996). Misbehavior in organizations: A motivational framework. Organization Science, 7(2), 151-165.

Weber, J., \& Getz, K. (2004). Buy bribes or bye-bye bribes: The future status of bribery in international commerce. Business Ethics Quarterly, 14(4), 695-711.

Weitzer, R., \& Tuch, S. A. (2004). Race and perceptions of police misconduct. Journal of Society for the Study of Social Problems, 51(3), 305-325.

Westmarland, L. (2005). Police ethics and integrity: Breaking the blue code of silence. Policing and Society, 15(2), 145-165. 


\section{Macrothink}

International Journal of Human Resource Studies

ISSN 2162-3058

\section{Copyright Disclaimer}

Copyright for this article is retained by the author(s), with first publication rights granted to the journal.

This is an open-access article distributed under the terms and conditions of the Creative Commons Attribution license (http://creativecommons.org/licenses/by/3.0/). 